\title{
KRITIK ILMU EKONOMI STRUKTURALIS DAN ISLAM TERHADAP EKONOMI NEOKLASIKAL
}

\author{
Handi Risza ${ }^{1}$
}

\begin{abstract}
The Critics of Structuralis Economics and Islam To Neo-Clasical Economy. This reserach proves that in the Islamic economic thought and structuralist discourse, the idea of economic and social transform is very strong, in the mean time, there is a lot of criticisms and corrections towards neoclassical economic thought. The idea of transformation is needed to reestablish economic credos and thoughts that put forward moral values and humanitarian system of ethics in the quest of economic justice and prosperity. The conclusion of this paper supports that there is an urgent need of social and economic transformation in order to establish social justice and economic prosperity. The conclusion is also a refutation to the views developed by neoclassical economic thinkers, who based their views on individual interest and free competition to realize prosperity and justice for the society.
\end{abstract}

Keyword: Economics, Neoclassical, Structuralis, Islam, Transformation

\begin{abstract}
Abstrak: Kritik Ilmu Ekonomi Strukturalis dan Islam Terhadap Ekonomi Klasikal. Penelitian ini membuktikan bahwa dalam wacana pemikiran ekonomi Islam dan strukturalis mengenai transformasi ekonomi dan sosial sangat kuat, sementara itu banyak gugatan dan koreksi terhadap paham ekonomi neoklasikal. Gagasan transformasi diperlukan untuk menyusun kembali paham ekonomi yang lebih mengedepankan nilai-nilai moral dan etika kemanusiaan, dalam mencapai keadilan dan kesejahteraan. Kesimpulan penelitian ini menyatakan bahwa diperlukan sebuah transformasi ekonomi dan sosial dalam rangka menciptakan keadilan ekonomi dan kesejahteraan sosial, sebagaimana yang disampaikan oleh para ekonom Muslim dan strukturalis. Penelitian ini membantah argumen yang dibangun oleh pemikiran ekonomi neoklasikal yang berbasis kepada pendekatan kepentingan individu dan persaingan bebas dalam menciptakan kesejahteraan dan keadilan bagi masyarakat.
\end{abstract}

Kata Kunci: Ekonomi, Neoklasikal, Strukturalis, Islam, Transformasi

${ }^{1}$ Diterima: 28 Maret 2014, direvisi: 5 Mei 2014, disetujui: 20 Mei 2014

Universitas Paramadina, The Energy Tower Lantai 22 SCBD Sudirman Jakarta, Email: handi@ paramadina.ac.id 


\section{PENDAHULUAN}

Umer Chapra (2000) mengungkapkan kegagalan ilmu Ekonomi Konvensional yang berbasis kepada Ekonomi Neoklasikal dalam mewujudkan keadilan dan kesejahteraan bagi semua orang. Lebih jauh Chapra mengungkapkan bahwa, ekonomi konvensional menjauhi pendekatan yang berdasarkan norma, konsentrasinya yang berlebihan pada maksimalisasi kekayaan, pemuasan keinginan serta pemenuhan kebutuhan perorangan. Pendekatan Ekonomi Neoklasikal tersebut, telah memunculkan istilah liberalisasi ekonomi dalam wujud globalisasi ekonomi.

Kondisi tersebut telah menimbulkan banyak permasalahan dalam perekonomian negara. Krisis keuangan yang berujung kepada krisis ekonomi akan menjadi bagian yang tidak terpisahkan dalam perjalanan ilmu ekonomi yang berbasiskan kepada pandangan ekonomi neo-klasikal. Seperti yang disampaikan Schumpeter (1972), bahwa ilmu ekonomi yang berbasis kepada pencarian kapital semata telah menciptakan suatu kerangka pikiran rasional, telah menghancurkan otoritas moral dan begitu banyak lembaga, pada akhirnya akan menghancurkan ilmu ekonomi itu sendiri. Krisis keuangan yang kemudian membesar menjadi krisis ekonomi, telah menjadi masalah besar bagi semua bangsa di dunia.

Roy Davies dan Glyn Davies dalam bukunnya The History of Money From Ancient time of Present Day mengungkapkan bahwa sepanjang abad 20 telah terjadi lebih 20 kali krisis besar yang melanda banyak negara. Fakta ini menunjukkan bahwa, secara rata-rata setiap 5 tahun terjadi krisis keuangan hebat yang mengakibatkan penderitaan bagi ratusan juta umat manusia. Kondisi ini tentu sangat mengkhawatirkan, oleh sebab itu perlu sebuah koreksi mendasar terhadap sistem ekonomi yang dianut oleh sebagian besar negara-negara didunia dewasa ini.

Disimpulkan oleh Swasono bahwa terdapat lima generasi yang mengusulkan perlunya mengakui the end of laissez-faire yang dilakukan oleh para ekonom baik dari Barat maupun yang berasal dari Timur. Pertama kali oleh tokoh besar John Maynard Keynes (1926); kedua oleh Moh. Hatta, Karl Polanyi (1934 dan 1944); ketiga oleh Gunnar Myrdal, John Kenneth Galbraith, Francis Bator, Paul Baran dll (1957- 1960); keempat oleh Robert Kuttner, Lester Thurow, George Soros, Josep Stiglitz, Susan George (1990-2002). Intinya adalah bahwa pasar tidaklah selfregulating, tidak self-correcting, penuh market failures, terutama dalam mengatasi ketimpangan struktural. Kelima adalah Para Nobel laureates 2006 (Edmund Phelps); 2007 (Eric Maskin, Loenid Hurwicz, Roger Myerson); 2008 (Paul Krugman); 2009 (Elinor Ostrom dan George Akerlof yang mendukung the end of laissez-faire.

Kritik yang dilontarkan kepada paham neoklasik tidak hanya dilakukan oleh kalangan strukturalis saja, tapi juga dilakukan oleh beberapa ekonom yang 
mengembangkan pemikiran Ekonomi Islam (Islamic Economic) diantara tokoh terkemukanya antara lain Umer Chapra, Najetulah Siddiqi, Khursyd Ahmad, dan ekonom Islam muda lainnya. Walaupun ekonomi Islam baru mengalami kebangkitan selama tiga-empat dekade terakhir, setelah tidur panjang selama berabad-abad. Ekonomi Islam sedang membangun sebuah struktur baru perekonomian dunia, ditengah merosotnya moral para pelaku ekonomi.

Dari penjelasan diatas terdapat titik temu antara pemikiran ekonomi strukturalis dan ekonomi Islam dalam dua substansi pokok permasalahan, yaitu menyelesaikan masalah ketidakadilan sosial dan mengatasi persoalan ketimpanganketimpangan struktural, sebagai masalah sosial-ekonomi yang selama ini muncul. Dalam mengatasi kedua substansi pokok tersebut, ekonomi struturalis dan ekonomi Islam juga memiliki titik temu yang sangat kuat untuk menyelesaikan, yaitu mengutamakan pendekatan kebersamaan dan kekeluargaan, dalam mengelola perekonomian. Dengan demikian, keinginan untuk melakukan transformasi ekonomi dan sosial akan semakin kuat.

Dari latar belakang masalah yang telah diuraikan di atas, ada beberapa permasalahan yang dapat diidentifikasikan, antara lain: Pertama, Neoklasikal berkeyakinan bahwa keseimbangan pada pasar bebas akan tercipta dengan sendirinya (invisible hand) dengan membentuk self-regulating dan self-correcting, tanpa campur tangan siapapun. Instrument yang digunakan adalah pasar persaingan bebas (free market competition) dimana kekuatan utamanya terletak pada efisiensi dan persiangan bebas (free competition). Kondisi inilah yang menyebabkan perilaku kapitalisme ekonomi muncul, karna adanya hegemoni untuk selalu memenangkan persaingan tanpa mengindahkan nilai-nilai moral dan kemanuasiaan.

Kedua, penguasaan sumber daya ekonomi yang hanya berputar disegelintir orang saja, telah menyebabkan perekonomian terdistorsi kedalam penguasaan sumberdaya ekonomi semata, akibatnya hubungan antar individu, pranata sosial berkurang bahkan menjadi hilang, yang pada akhirnya menimbulkan masalah ekonomi sosial di masyarakat seperti, kemiskinan, pengangguran, ketimpangan struktur dan ketimpangan pendapatan.

Oleh sebab itu munculnya trasnformasi ekonomi yang digagas oleh ekonom dan tokoh yang beraliran strukturalis dan Islam haruslah diapresiasi secara mendalam, keinginan untuk menciptakan sistem ekonomi yang adil dan memberikan kesejahteraan penuh bagi masyarakat adalah sebuah keinginan dan cita-cita mulia. Transformasi ekonomi yang digagas haruslah memiliki dampak dan pengaruh yang kuat terhadap sistem ekonomi dan sosial kemasyarakatan. Diperlukan kajian, pemikiran yang mendalam dan konsisten agar keinginan dan cita-cita transformasi tersebut bisa berhasil. Indonesia memiliki peluang untuk menjadi role model bagi 
negara berkembang, karena sudah memiliki dasar negara yang sejalan dengan citacita dan keinginan transformasi tersebut. Kondisi tersebut telah tertuang dalam konstitusi negara yaitu pasal 27, 33 dan 34 UUD 1945.

\section{METODE}

Metode penelitian yang dilakukan dalam penelitian ini, dilakukan dalam beberapa bentuk penelitian, Antara lain:

1) Studi kepustakaan

Studi kepustakaan atau studi literatur yang digunakan dalam penelitian ini untuk menghimpun semua pemikiran dan teori yang berkembang dalam ranah ekonomi neo-klasikal, ekonomi strukturalis dan ekonomi Islam. Semua literatur yang terkumpul kemudian dianalisa dan disusun keterkaitan antara satu paham ekonomi dengan paham ekonomi lainnya. Sehingga nantinya akan terlihat hubungan antara teori yang berkembang dengan implikasi yang ditimbulkannya di lapangan.

2) Observasi data

Metode observasi yang digunakan adalah metode yang menggunakan data yang telah tersedia (Research with available data), yang diadaptasi dari metode penelitian Royce A. Singleton- Bruce C. Straith (1999) dan Earl Babbie (1998). Metode penelitian ini dimanfaatkan untuk menganalisis proposisi paradigma dan asumsi dasar dan kebijakan yang ditimbulkan dari paham ekonomi strukturalis dan ekonomi Islam dalam menanggapi persoalan pokok ekonomi mengenai ketidakadilan sosial dan ketimpangan struktural yang ditimbulkan oleh kebijakan ekonomi paham neoklasikal. Proposisi-proposisi ini nantinya akan diuji validitasnya dalam menjawab permasalahan pokok ekonomi tersebut.

Pendekatan yang digunakan dalam penelitian ini menggunakan dua pendekatan, yaitu pendekatan sosio-historik dan pendekatan ekonomi politik. Adapun penjelasannya adalah sebagai berikut:

1) Pendekatan sosio-historik

Pendekatan sosio-historik digunakan untuk memahami sejarah munculnya paham eonomi neoklasikal. Penelitian ini dimulai dengan meneliti karakteristik sistem Ekonomi Neoklasikal semenjak Adam Smith dengan karyanya The Wealth of Nations (1776) hingga Mankiw (2010) dengan karyanya The Economics Theory. Meneliti pikiran-pikiran Ekonomi Strukturalis mulai dari Karl Polanyi dengan karyanya The Great Transformation (1957) hingga Joseph E. Stiglizt dengan karya terakhirnya Free Fall (2010). 
2) Pendekatan ekonomi-politik

Pendekatan ekonomi politik digunakan untuk melihat implikasi kebijakan yang ditimbulkan dari pemikiran paham ekonomi neo-klasikal. Dari persoalan yang timbul, kemudian dianalisa secara mendalam penyebab dan solusi yang seharusnya dilakukan, dengan menggunakan pendekatan paham ekonomi strukturalis dan ekonomi Islam. Solusi yang dihasilkan akan berdampak secara ekonomi dan politik dalam bentuk kebijakan ekonomi sebuah negara.

\section{KRITIK EKONOMI STRUKTURALIS DAN ISLAM}

Kedudukan ilmu ekonomi sebagai ilmu yang berbasiskan kepada moralitas sesungguhnya telah dimulai oleh Adam Smith. Sebelum menerbitkan bukunya yang sangat terkenal An Inquiry Into The Nature and Cause of The Wealth of Nation pada tahun 1776, Smith telah menerbitkan The Theory of Moral Sentiments, pada tahun 1759. Dimana Smith menggambarkan tentang empati dan kecenderungan cinta kasih kepada masyarakatnya. Dalam perjalanannya terjadi perubahan pemikiran yang dilakukan oleh Smith, melalui The Wealth of Nation terlihat inkonsistensi Smith yang dikenal sebagai das Smith Problem (The Problem of Smith) dalam pandangannya terhadap etika individu dalam aktifitas ekonomi.

Perubahan pandangan Smith tersebut disikapi berbeda oleh para pengikutnya yang di kemudian hari dikenal dengan nama kaum neoklasikal, mereka mengabaikan pemikiran Smith yang tertuang dalam buku yang awal The Theory of Moral Sentiments (1759) dan mengedepankan serta merujuk pandangan Smith pada buku yang hadir belakangan An Inquiry Into The Nature and Cause of The Wealth of Nation (1776). Dalam perkembangan pemikiran kaum neo-klasikal cenderung mengabaikan implikasi asumsi monoutilitas, dengan demikian mengabaikan kenyataan bi-utilitas yang menjadi pokok pikiran dalam buku The Theory of Moral Sentiments. Artinya kaum neo-klasikal hanya merujuk kepada satu pemikiran Smith semata, sementara sisi lain dari pemikiran Smith cenderung diabaikan.

Dalam perkembangannya gagasan Smith dalam The Wealth of Nation diperbaharui oleh Paul Samuelson dalam bukunnya Economics An Introductory Analysis. Semenjak itu, lebih tepatnya semenjak perang dunia II ilmu ekonomi yang diajarkan dan diterapkan di seluruh dunia dirintis oleh buku Samuelson tersebut. Inti ajaran yang dikemukakan oleh Samuelson, kemudian dikenal sebagai teori ekonomi neo-klasikal.

Dengan sangat cepat paham neo-klasikal telah mempengaruhi pengajaran ilmu ekonomi hampir diseluruh negara di dunia, tidak terkecuali di Indonesia. Neo-klasikal membangun konsep dan pengajaran ilmu ekonominya dengan 
mengedepankan asumsi-asumsi dasar yang bersumber dari pemikiran Smith dan secara modern diperbaharui oleh Samuelson, yaitu bahwa; (1) keinginan manusia yang bersifat tidak terbatas (2) Sumber-sumber ekonomi yang digunakan untuk memenuhi keinginan manusia yang terbatas dan (3) Pengejaran akan pemenuhan maksimal kebutuhan individual yang relatif tidak terbatas.

Dampak dan konsekuensi dari ketiga asumsi dasar itu berkelanjutan dengan suatu anggapan bahwa akhlak dasar manusia adalah bertarung dan saling berebut untuk dirinya sendiri. Asumsi dasar inilah yang kemudian melahirkan konsep efisiensi dalam mencapai tujuan tertentu baik dalam bentuk kepuasan pribadi (maximum satisfaction) maupun keuntungan maksimal (maximum profit).

Pemikiran ilmu ekonomi neo-klasikal kemudian berkembang dengan pesat, dengan fokus kajian yang semakin luas yang menyangkut pembentukan pasar dan manusianya (homo economicus dan invisible hand), dengan pendekatan marginal utility serta keseimbangan umum (general equilibrium). Fokus pengajaran ekonomi neo-klasikal adalah bahwa mekanisme pasar persaingan bebas, dengan asumsiasumsi tertentu, selalu menuju keseimbangan dan efisiensi optimal yang baik bagi semua orang, dengan meminimalisir peran dan fungsi regulator dalam hal ini adalah pemerintah. Artinya jika pasar dibiarkan bebas, tidak diganggu oleh aturan-aturan pemerintah yang bertujuan baik sekali pun, masyarakat secara keseluruhan akan mencapai kesejahteraan bersama yang optimal, dimana semua orang akan menjadi sejahtera tanpa harus mengorbankan orang lain atau pihak lain.

Neo-liberalisme merupakan wujud baru dari liberalisme sebagaimana neo-kapitalisme adalah wujud baru dari kapitalisme. Dengan memanfaatkan isu globalisasi mereka terus bergerak untuk mengkampanyekan ide dan gagasan tentang liberalisasi ekonomi dalam pasar bebas dan persaingan bebas, jadi bisa dikatakan globalisasi merupakan persemaian baru dari gagasan liberalisme dan kapitalisme ekonomi dengan kata lain menemukan kembali mantelnya yang baru yang lebih radikal.

Setidaknya terdapat empat faktor yang mempengaruhi dan mengiringi kemunculan neo-liberalisme. Pertama, munculnya perusahaan-perusahaan multinasional dengan aset lebih besar dari kekayaan negara-negara kecil di dunia. Perusahaan-perusahaan ini mampu menembus batas teritori negara-negara sekaligus memanfaatkan infrastruktur negara tersebut. Kedua, munculnya rezim-rezim internasional sebagai surveillance system untuk menjamin negara-negara patuh dan tunduk pada hukum pasar bebas. Rezim-rezim itu adalah World Trade Organization (WTO), World Bank (WB), dan International Monetary Fund (IMF), Ketiga, revolusi teknologi komunikasi dan transportasi yang dahsyat, yang memudahkan bagi para pemilik modal untuk mengetahui perkembangan dan situasi sosial, ekonomi 
dan politik di sebuah negara. keempat, dari perspektif realis bahwa negara-negara maju memakai kekuatannya untuk melakukan hegemoni terhadap negara-negara berkembang. Mereka berkeyakinan bahwa masyarakat di seluruh dunia akan mendapatkan kemakmuran kalau semua negara di dunia ini mau saling membuka perbatasannya, dalam hal ini menciptakan pasar bebas. Barang-barang dapat keluar dan masuk dengan bebas, begitu juga investasi, dalam konteks ini adalah terciptanya persaingan bebas antar sesama pelaku ekonomi.

Basis utama para pendukung neo-liberalisme ini adalah teori atau pandangan liberalisasi terhadap ekonomi. Teori neo-liberalisme bisa dikatakan sebagai teori yang paling optimistis dan meyakini akan terciptanya kemakmuran dan kesejahteraan masyarakat dunia. Mereka berpendapat bahwa struktur pasar internasional saat ini akan dapat membawa kemakmuran yang dicita- citakan. Dunia memang terbagi antara negara-negara maju dan negara sedang berkembang. Meski demikian, di antara keduanya tidak perlu terjadi antagonisme. Keduanya dapat bekerja sama untuk menciptakan kemakmuran dunia. Oleh sebab itu globalisasi akan mendapat tempat yang sangat pas dalam isu liberalisme ekonomi, karena akan bertujuan untuk mempersempit ruang antar negara, sehingga memungkinkan antar negara akan saling berhubungan tanpa ada hambatan yang berarti dari sisi teritori.

Tetapi di sisi lain para pakar yang mengusung paham ini, mengakui terdapat sejumlah kelemahan yang akan menjadi hambatan dalam menjalankan konsep ini. Permasalahan yang bisa ditimbulkan menurut pendukung teori liberalisme adalah kelemahan yang terkandung dalam berbagai faktor produksi, terutama modal dan tenaga kerja, di mana keduanya merupakan unsur faktor produksi yang sangat penting dalam menciptakan output. Teori liberalisme meyakini ada cara untuk mengatasi masalah yang ditimbukkan oleh faktor produksi tersebut terutama mengenai modal dan tenaga kerja. Terdapat tiga pendekatan yang digunakan, anatara lain adalah: perdagangan, investasi asing, dan hutang luar negeri.

Jadi sangat jelas bahwasanya gagasan globalisasi telah menuai banyak kecaman dari banyak pakar bahkan menimbulkan kekecewaan, yang mungkin sebelumnya tidak terbayangkan oleh para penggagasnya. Banyak persoalan yang akan menghadang dan perlu diselesaikan terlebih dahulu, seperti; kemiskinan, pengangguran, kepastian hidup, ketidakstabilan, kerusakan budaya, jurang pemisah antara yang kaya dan miskin, dan permasalahan sosial lainnya. Oleh sebab itu perlu kiranya dicari sebuah terobosan baru, memperbaiki tata ekonomi dengan melibatkan secara bersama-sama pelaku ekonomi, mulai dari individu, komunitas, perusahaan, dan negara, sehingga perekonomian akan tumbuh dan berkembang sesuai dengan harapan dan keinginan masyarakat. 


\section{Kritik Ekonomi Strukturalis Terhadap Ekonomi Neo-Klasikal}

Munculnya paham ekonomi strukturalis merupakan reaksi dari dominasi aliran ekonomi neo-klasikal yang selama ini banyak diterapkan di negara-negara maju, tetapi kemudian menimbulkan banyak masalah ketika diterapkan di negaranegara berkembang. Sehingga mulai memunculkan banyak kritik dari para ekonom. Isu-isu mengenai krisis finansial global, kemiskinan, pengangguran, ketimpangan sosial, keresahan sosial dan kerusakan lingkungan, selama ini menjadi ancaman tersendiri bagi negara berkembang.

Paradigma ekonomi yang berkembang di negara maju coba untuk diterapkan di negara-negara yang sedang berkembang. Hampir semua negara berkembang memiliki sumber daya alam, tetapi miskin sumber daya manusia. Untuk mengejar ketertinggalan dari negara maju, terdapat tiga resep yang selalu digunakan untuk negara berkembang (Todaro, 1989). Pertama, pertumbuhan ekonomi yang tinggi. Kedua, untuk membiayai pembangunan khususnya infrastrutur, dibiayai dengan utang luar negeri. Ketiga, membuka pasar, agar investasi dalam bentuk penanaman modal asing bisa masuk ke negara-negara sedang berkembang. Ketiga kebijakan tersebut, telah menjadi bagian dari kebijakan pembangunan ekonomi di negara berkembang. Para ekonom di negara-negara maju dan lembaga atau donor internasional ketika itu berkeyakinan, bahwa pasar bebas akan lebih efisien dalam alokasi segenap sumber daya ketimbang campur tangan pemerintah. Praktis pembangunan lebih banyak dikendalikan oleh negara dan lembaga donor asing.

Dilema utama yang dihadapi oleh sebagian besar negara-negara berkembang adalah, ternyata pembangunan ekonomi yang yang mereka lakukan selama ini justru menimbulkan persoalan baru yang sangat pelik. Apa yang telah diusulkan selama ini untuk mempercepat ketertinggalan dari negara maju tidak terbukti. Akibatnya, kemiskinan, pengangguran dan ketimpangan pendapatan telah menjadi masalah besar disebagian besar negera berkembang. Berbagai kegagalan struktural dari perekonomian global ini telah menciptakan bencana ekonomi (economic disaster) yang luar biasa di tengah-tengah keajaiban ekonomi (economic miracle) dunia. Kemiskinan, ketimpangan pendapatan, dan pengangguran telah melahirkan berbagai tragedi kemanusiaan yang luas dan dalam

Sistem ekonomi yang digunakan oleh sebagian besar negara berkembang saat ini sangat dipengaruhi oleh pemahaman neoklasikal ekonomi, ternyata tidak mampu menyelesaikan masalah yang timbul akibat pembangunan ekonomi. Oleh sebab itu, perlu sebuah pendekatan baru dalam mengelola perekonomian, khususnya perekonomian dinegara berkembang. Ekonomi strukturalis dalam perkembangannya, telah menjadi bidang ilmu tersendiri. Bahkan beberapa tokohnya telah meraih nobel ekonomi. Gunnar Myrdal yang memperoleh hadiah 
Nobel Ekonomi pada tahun 1974 menyatakan dalam bukunya Asian Drama. An Inquiry in to the Poverty of Nations bahwa teori ekonomi yang sekarang diajarkan dan diaplikasikan di seluruh dunia adalah berbasis kepada aliran neo-klasik yang cocok untuk negara maju. Menurutnya teori ekonomi tersebut tidak dikembangkan untuk menganalisis masalah-masalah ekonomi negara-negara sedang berkembang, oleh karenanya bagi negara sedang berkembang diperlukan teori yang lain dengan negara maju karena perbedaan masalah sosial, ekonomi, politik, hukum dan budaya.

Munculnya pandangan strukturalis yang melakukan koreksi terhadap kebijakan ekonomi yang dipengaruhi oleh paham neo-klasikal, telah memberikan pencerahan terhadap kebuntuan ekonomi selama ini. Terutama pada kondisi terjadinya ketimpangan struktural sebagai sumber ketidakadilan sosial-ekonomi. Para ekonom strukturalis mencoba menguraikan bagaimana ketinpangan yang telah menimbulkan permasalahan ekonomi tersebut, terutama yang berkaitan dengan pemusatan penguasaan dan pemilikan aset ekonomi, ketimpangan distribusi pendapatan, produktivitas dan kesempatan ekonomi. Selain itu juga terdapat ketimpangan dalam kelembagaan, ekonomi partisipasi, dan emansipasi sosial-ekonomi, pengangguran, kemiskinan, dan masalah ketergantungan serta subordinasi sosial-ekonomi.

Pandangan strukturalis mencoba mengembalikan ilmu ekonomi pada peran normatifnya, menjelajahi komposisi dan inter-relasi antara para aktor, sektorsektor dan variabel-variabel ekonomi dalam rangka mewujudkan keadilan dan kesetaraan sosio-ekonomi. Untuk mewujudkan gagasan tersebut kaum strukturalis mengusulkan perlunya dilakukan transformasi ekonomi dan transformasi sosial dalam kebijakan ekonomi sebuah negara. Tentu tuntutan strukturalis ini tidak mudah, karena akan langsung berhadapan dengan kepentingan ekonomi global yang hari ini telah menguasai sumber daya ekonomi di banyak negara. Pandangan strukturalis mencoba melakukan koreksi terhadap kelemahan mendasar dari mekanisme pasar dan persaingan bebas, yang tidak mampu mengatasi ketimpanganketimpangan struktural yang semakin mengemuka, baik antar kaum pemilik modal dan buruhnya, maupun antar negara maju dengan negara miskin. Oleh sebab itu strukturalisme berorientasi kepada strukturisasi dan restrukturisasi ekonomi yang disertai dengan intervensi mengatur dan mengontrol mekanisme pasar.

Ide dan gagasan tentang transformasi yang dilakukan untuk mengembalikan kedaulatan ekonomi oleh para pemikir strukturalis telah menjelma sebagai gagasan alternatif yang siap untuk dijalankan. Kajian mengenai konsep transformasi ini, akan lebih mengutamakan pendekatan yang humanitarian, dimana pembangunan manusia dengan segala perangkatnya yang akan diutamakan. Gagasan transformasi di Indonesia sesungguhnya bukanlah gagasan yang baru, jauh hari Bung Hatta 
selaku konseptor dasar ekonomi Indonesia sudah mengingatkan akan hal tersebut. Gagasan pemikiran bung Hatta adalah perlunya perekonomian nasional melakukan transformasi ekonomi dan transformasi sosial, apabila bangsa dan negara benarbenar ingin melepaskan diri dari sistem ekonomi penjajah yang subordinatif dan serba ketergantungan.

\section{Kritik Ekonomi Islam Terhadap Ekonomi Neo-Klasikal}

Perkembangan Ekonomi Islam dalam beberapa tahun terakhir telah memberikan wacana baru dalam perkembangan ilmu ekonomi kontemporer. Islam sebagai pandangan hidup (way of life) tidak hanya berperan sebagai sebuah agama tetapi sebuah jalan hidup yang diyakini oleh pemeluknya untuk diikuti dan ditaati. Oleh sebab itu pendekatan yang ditawarkan dalam ekonomi Islam akan sangat berbeda sekali dengan pendekatan yang selama ini dipelajari dalam ekonomi umum atau yang lebih dikenal dengan istilah ekonomi konvensional, sebagaimana yang kita ketahui bersama sangat dipengaruhi oleh paham neo-klasikal ekonomi.

Ajaran Islam telah memberikan tuntunan pada seluruh aspek kehidupan, baik hubungan manusia dengan tuhan, atau manusia dengan sesama mahluk tuhan lainnya. Faktor inilah yang membuat ajaran Islam sangat komprehensif dan menyeluruh ( $k a f f a h$ ), tidak ada pemisahan antara urusan duniawi dengan akhirat yang selama ini sangat dipengaruhi oleh pemikiran kapitalisme ekonomi. Implementasi Islam secara kaffah mencakupi kepatuhan dan ketundukan dalam menjalankan ajaran Islam secara keseluruhan, termasuk juga ketika dalam melaksanakan aktifitas ekonomi. Pandangan Islam telah memposisikan kegiatan mu'amalah dimana didalamnya terdapat aktifitas ekonomi sebagai salah satu aspek penting untuk mendapatkan kemuliaan, oleh sebab itu semua kegiatan ekonomi perlu tuntunan dan control yang kuat agar berjalan sebagaimana yang telah diajarkan dalam Islam secara keseluruhan. Falah hanya dapat diperoleh jika ajaran Islam dilaksanakan secara kaffah.

Munculnya Ekonomi Islam sebagai sebuah pandangan baru dalam ekonomi tidak lepas dari para sarjana-sarjana ekonomi yang berbasis di Timur tengah, Pakistan, Banglades dan Malaysia, yang sebagian besar dari mereka telah mengenyam pendidikan tinggi di universitas-universitas ternama di Amerika dan Eropa. Timbulnya kesadaran untuk terus memperdalam Islam sebagai ideologi dalam ilmu ekonomi, tidak lepas dari keresahan mereka terhadap perkembangan ilmu ekonomi konvensional yang semakin menggiring ilmu ekonomi ke arah yang sangat hedonis, mengabaikan nilai-nilai moral dan kemanusiaan, sehingga yang tinggal hanya kerakusan semata. 
Momentum terbesar dalam sejarah perkembangan ilmu Ekonomi Islam adalah diselenggarakannya seminar internasional pertama yang bertemakan tentang perkembangan Ekonomi Islam di Mekkah, Saudi Arabia. Pada kesempatan tersebut mulai bermunculan pakar dan ekonom Islam yang kelak akan mempengaruhi pemikiran Ekonomi Islam. Perlahan namun pasti pemikiran Ekonomi Islam mulai dipelajari diberbagai perguruan tinggi dunia, mulai dari sebagai mata kuliah, hingga memiliki program tersendiri sampai pada level doktoral. Ekonomi Islam yang bersumber dari nilai Islam, telah membalikkan paradigma ekonomi yang berpaham neo-klasikal yang selama ini telah menjadi mainstream di kalangan fakultas ekonomi hampir di seluruh dunia. Ekonomi Islam telah dibangun dengan dasar yang sangat kokoh, yaitu bersumber dari sumber utama (primary resources) Al-Quran dan Sunnah, yang merupakan sumber rujukan utama dari ajaran Islam. Bisa dipastikan kekuatan moral dan nilai akan menjadi karakteristik yang tidak bisa dipisahkan dalam ilmu ekonomi Islam. Dalam ekonomi Islam sesungguhnhya tidak terdapat pemisahan yang ekstrim antara tujuan positif dengan tujuan normatif, semuanya saling melengkapi dan saling mempengaruhi (Khan, 1994). Manusia dituntun dengan ketentuan yang sudah baku, sehingga setiap individu akan memiliki orientasi yang jelas dalam melakukan setiap aktivitas ekonominya. Ekonomi Islam telah mengembalikan peran moral dalam pencapaian setiap tujuan ekonominya, hal tersebut telah dijamin dalam Maqashid Syariah. Dengan semakin memperkuat diri dari segi metodologinya, perkembangan ekonomi Islam juga bisa tergambar dari perkembangan sistem keuangan Islam yang sangat dinamis. Pertumbuhan lembaga keuangan Islam di banyak negara telah mampu mengalahkan pertumbuhan lembaga keuangan umum dimana dari sisi usia dan pengalaman sudah melebihi dari lembaga keuangan Islam.

Selain mempengaruhi paradigma terhadap ilmu ekonomi yang sekarang dipahami oleh masyarakat, ilmu ekonomi Islam telah menawarkan tugas penting yang bisa dilakukan untuk membuka ruang melakukan perbaikan, atau proses transformasi ekonomi dan sosial yang memiliki implikasi terhadap kehidupan masyarakat kelak. Gagasan ekonomi Islam dalam memperbaiki kondisi tersebut antara lain: Pertama, memperbaiki dan membenahi perilaku individu, kelompok, pasar dan pemerintah yang selama ini tidak terlalu peduli dengan pendekatan moral. Sebagian besar ajaran Islam memaparkan tentang konsep perilaku (behavior) mulai dari individu hingga negara. Sehingga ekonomi Islam telah memiliki modal awal yang sangat berharga dalam membenahi perilaku masyarakat.

Kedua, mengimplementasikan dalam bentuk formulasi yang bisa langsung diakses oleh masyarakat mengenai tujuan dan sasaran setiap perilaku dan tingkah laku individu dan masyarakat. Sehingga setiap adanya perubahan, akan langsung bisa 
dideteksi. Dengan demikian pencapaian tujuan dalam ekonomi Islam harus selaras dengan nilai-nilai kemanusiaan dan lingkungannya. Ketiga, melakukan perubahan terhadap hubungan baik yang bersifat personal maupun kelembagaan yang ada di tengah masyarakat, sehingga hubungan antar setiap komponen akan menciptakan pranata sosial baru yang berorientasi kepada nilai-nilai kemanusiaan dalam rangka mencapai tingkat keadilan dan kesejahteraan bagi masyarakat.

Keempat, menyiapkan strategi dan kebijakan yang praktis untuk melakukan transformasi ekonomi dan sosial di tengah-tengah masyarakat. Proses transformasi ekonomi dan sosial yang dibangun harus tetap berorientasi kepada nilai-nilai kemanusiaan yang sangat kental dalam Islam. Sehingga pengalokasian dan pendistribusian setiap sumber daya ekonomi akan bisa dirasakan oleh semua lapisan masyarakat tanpa terkecuali.

Oleh sebab itu peran ekonomi Islam dalam mendorong transformasi ekonomi harus terus dilakukan, kekayaan nilai-nilai moral dan spiritual harus menjadi modal dasar untuk mengilhami lahirnya kekuatan ekonomi yang berpihak pada nilai-nilai kemanusiaan sejati. Ekonomi Islam harus mampu menawarkan sesuatu yang komprehensif untuk menjawab kelemahan sistem ekonomi yang selama ini berkembang

Banyaknya kritik yang dilakukan kepada aliran ekonomi neo-klasikal oleh berbagai kalangan ilmuwan, merupakan cermin kegagalan dalam pemikiran, pendidikan, penelitan, dan pengambilan kebijakan yang bertumpu kepada aliran ekonomi neo-klasikal. Aliran ekonomi neo-klasikal yang mengandalkan kepada kebebasan ekonomi dan terlalu mengandalkan kepada superioritas mekanisme pasar dan invisible hand, pada kenyataannya justru menimbulkan masalah sosial dalam perekonomian, terjadinya ketimpangan struktural eksploitasi baik oleh negara kuat terhadap negara lemah, perusahaan atau institusi yang kuat terhadap usaha atau institusi yang lemah (Perkins, 2004). Inilah yang kemudian menjadi titik tolak mengenai kebutuhan akan paradigma baru ilmu ekonomi dalam bentuk transformasi ekonomi dan transformasi sosial.

Dalam hal ini, bisa dipastikan bahwa aspek moralitas dalam bentuk nilai-nilai kebersamaan dan kekeluargaan dianggap tidak begitu penting. Akibatnya adalah, munculnya persoalan kemiskinan, ketimpangan dalam distribusi pendapatan, kerusakan lingkungan, berkembangnya budaya materialistik. Kondisi tersebut tidak bisa dipisahkan dari keberadaan aliran ekonomi neo-klasikal yang mempengaruhi paham dan cara pandang dalam perekonomian. Paham ekonomi neo-klasikal telah menciptakan identitasnya sendiri, munculnya individu-individu yang sangat fanatik terhadap paham tersebut, telah memunculkan ketergantungan yang sangat rentan terhadap mekanisme pasar. Mekanisme pasar telah mengkerdilkan peran pemerintah, 
dengan memberikan peran yang minimal dalam perekonomian. Perekonomian di bawah sistem yang didasari oleh paham neo-klasikal semakin menjauh dari harmoni antara kepentingan pribadi dan kepentingan sosial.

Semakin disadari bahwa sistem ekonomi yang sekarang ada gagal mewujudkan kesejahteraan dan pemerataan dalam tatanan sosial-ekonomi dalam masyarakat. Namun, alih-alih menyelesaikan konflik antara tujuan normatif dan strategi sekuler serta memperbaiki asumsi dan struktur logika yang mengiringi-nya, ekonom justru semakin tenggelam dalam kecanggihan matematika. Hal ini tidak saja membuat ilmu ekonomi semakin abstrak dan sulit, namun juga semakin tidak relevan dengan pembuatan kebijakan.

Ilmu ekonomi dikembalikan kepada akarnya, yaitu ilmu yang bersumber kepada nilai nilai kemanusiaan yang didasarkan kepada nilai-nilai dan norma agama, dimana terdapat keseimbangan antara tujuan positif dan normatif yang ingin dicapai, perlu sebuah pendekatan baru dalam merumuskan hubungan atau relasi antar pelaku ekonomi. Proses pencapaian kesejahteraan manusia tetap mengacu kepada nilai nilai dan norma yang berlaku di masyarakat. Kekuatan kebersamaan (mutualism) dan persaudaraan (brotherhood) bisa menjadi solusi dalam mengatasi masalah ketidakadilan sosial dan ketimpangan struktural. Dengan demikian, kesejahteraan dan kebahagian manusia tidak semata berlaku secara individual tetapi juga bersifat sosial, dalam ekonomi Islam kemudian dikenal dengan istilah falah atau kebahagiaan dunia dan akhirat. Perekonomian akan kembali kepada fungsi semulanya yaitu memberikan penghidupan yang layak. Keadilan dan kesejahteraan bagi masyarakat.

Transformasi ekonomi adalah suatu upaya restrukturisasi terhadap paham dan pemikiran ekonomi tertentu, dalam rangka mengembalikan atau membentuk sistim ekonomi baru. Upaya untuk menggagas kembali trasnformasi ekonomi, haruslah dimulai dengan merubah paradigma yang selama ini berkembang dan asumsi dasar yang selama terbangun dalam paham dan cara pandang yang lama, diantarannya yaitu meninggalkan asas perorangan dan menggantinnya dengan paham kebersamaan dan asas kekeluargaan, atau dengan kata lain merubah sistem ekonomi yang subordinatif menjadi sistem ekonomi nasional yang demokratis berdasarkan demokrasi ekonomi.

Proses berjalannya transformasi ekonomi tidak bisa dipisahkan dari transformasi sosial. Tranformasi sosial akan membentuk pola-pola baru dalam hubungan ekonomi dan sosial di masyarakat, dalam hal ini akan membentuk hubungan ekonomi yang partisipatori-emansipatori, terbentuk pola kemitraan yang saling menjaga dan memiliki satu dengan yang lain. Jika pola tersebut dipertahankan, maka akan timbul sebuah budaya baru dalam mengelola perekonomian dalam 
masyarakat.

Perlu disusun tahapan tahapan yang akan digunakan dalam melakukan proses transformasi ekonomi dan sosial. Pertama, tahapan yang bersifat fundamental yaitu membangun kembali paradigma baru dan asumsi dasar dalam pemahaman dan pengajaran ilmu ekonomi. Langkah pertama ini sangat penting, karena dasar dari pengembangan ilmu ekonomi ada pada paradigma dan asumsi dasar. Proses internalisasi paham ekonomi kepada masyarakat terutama level pelajar dan mahasiswa dimulai dari bangku sekolah dan universitas. Kedua, tahapan yang bersifat aplikasi. Proses restrukturisasi kebijakan ekonomi berada pada tahapan ini. Tahapan ini tidak hanya sekedar merumuskan kebijakan ekonomi baru tetapi juga melakukan restrukturisasi terhadap kebijakan-kebijakan ekonomi sebelumnya, yang tidak sesuai dengan nilai-nilai luhur demokrasi ekonomi, yang sudah dituangkan dalam konstitusi negara.

Proses transformasi ekonomi tidak hanya sekedar mengganti paham dan cara pandang terhadap ekonomi yang baru semata, tetapi juga merubah cara berfikir dan berperilaku setiap individu yang menjalankannya. Oleh sebab itu perubahan paradigma dan asumsi dasar menjadi suatu hal yang tidak bisa dihindari dalam memulai proses transformasi. Setelah persoalan mendasar tersebut selesai barulah kemudian mempersiapkan perangkat perangkat yang akan menjadi instrumen dalam proses transformasi ekonomi tersebut.

Tahapan selanjutnya adalah melaksanakan atau kembali kepada demokrasi ekonomi secara konsisten sesuai dengan kepribadian dan karakter masyarakat. Demokrasi ekonomi telah disusun oleh para pendiri bangsa dengan memperhatikan aspek-aspek internal kebangsaan, tetapi juga memperhatikan aspek-aspek eksternal yang dipersiapkan untuk menghadapi tantangan masa depan yang lebih sulit. Demokrasi ekonomi diharapkan akan menjadi dasar dalam setiap pengambilan kebijakan yang dipergunakan untuk kesejahteraan bangsa dan negara.

Besarnya pengaruh dan cara pandang paham ekonomi neo-klasikal dalam perekonomian nasional, telah menyebabkan nilai-nilai dasar yang menjadi ciri dan karakter perekonomian nasional sudah mulai terkikis. Proses transformasi yang dilakukan bertujuan untuk mengembalikan ciri dan karakter perekonomian nasional kedalam nilai dasarnya, yaitu melaksanakan usaha bersama dalam membangun perekonomian, sehingga setiap potensi yang dimiliki warga negara akan mampu memberikan kontribusi dalam pembangunan. Selain itu mengembalikan semangat kebersamaan dan asas kekeluargaan dalam kehidupan ekonomi dan sosial masyarakat. Sehingga diharapkan nantinya perekonomian nasional akan memiliki fundamental ekonomi yang kuat dalam menghadapi persaiangan global. 
Proses transformasi ekonomi akan selalu diikuti dengan terjadinnya transformasi sosial dalam perekonomian. Nilai-nilai dasar yang sudah terbentuk dalam transformasi ekonomi, kemudian ditransformasikan kedalam bentuk hubungan antar individu pelaku ekonomi yang lebih seimbang, berkeadilan dan harmonis. Hubungan antar pelaku ekonomi yang selama ini mengarah kepada pola-pola kolonialisme seperti hubungan antara kaum pemilik modal dengan para pekerja, hubungan antara majikan dan pembantunya. Pola hubungan sosial yang terbentuk adalah lebih bersifat kemitraan dan kerjasama yang saling menguntungkan tanpa ada yang merasa dirugikan atau dieksploitasi. Atau dengan kata lain akan membentuk hubungan ekonomi partispatori-emansipatori.

\section{SIMPULAN}

Dari neo-klasikal lahirlah paham fundamentalisme pasar (market fundamentalism), yaitu mekanisme persaingan bebas (free perfect competition) dengan pasar bebas sempurna (free perfect market). Konsekuensi logis dari paham tersebut kemudian melahirkan konsepsi kapitalisme global dan globalisasi ekonomi. Cara pandang tersebut telah terinternalisasi dan tersosialisasi dalam kehidupan masyarakat selama bertahun-tahun. Ketika isu globalisasi muncul, hampir semua negara mempersiapkannya dengan terbuka, berbicara dalam konteks bilateral maupun multilateral. Tanpa pernah disadari, sesungguhnya globalisasi ekonomi juga menimbulkan kekecewaan (discontent) dalam bentuk ketimpangan (inequality) yang semakin lebar antar negara, ketimpangan struktural antar pelaku ekonomi, persoalan sosial ekonomi seperti kemiskinan yang semakin parah, tingkat pengangguran yang semakin meningkat.

Oleh sebab itu diperlukan paradigma baru dalam bentuk transformasi ekonomi untuk menata ulang konsepsi globalisasi. Terdapat titik temu antara pemikiran Ekonomi Strukturalis dan Ekonomi Islam dalam dua substansi pokok permasalahan, yaitu menyelesaikan masalah ketidakadilan sosial dan mengatasi persoalan ketimpangan-ketimpangan struktural, sebagai masalah sosial-ekonomi yang selama ini muncul. Dalam mengatasi kedua substansi pokok tersebut, ekonomi struturalis dan Ekonomi Islam juga memiliki titik temu yang sangat kuat, yaitu mengutamakan kebersamaan dan kekeluargaan.

\section{PUSTAKA ACUAN}

Al-Mannan, M.A. 1992. "The Behaviour of Firm and Its Objectives in an Islamic Framework." dalam S. Taher, Readings in Microeconomics: an Islamic Perspective. Malaysia: Longman. 
Ackerman, F, et al. 1998. The Political Economy of Inequality. Washington DC: Island Press.

Ahmad, K. 1981. Studies in Islamic Economics. Leicester UK: The Islamic Foundation.

Amin, A.R. 2007. Satanic Finance True Conspiracies. Jakarta: Celestial Management.

Arief, S. 1983. Pemikiran Pembangunan dan Kebijakan Ekonomi. Jakarta: Lembaga Riset Pembangunan.

Arsyad, L. 1997. Ekonomi Pembangunan. Yogyakarta : STIE YKPN BPFE.

Baran, P. 1968 The Political Economy of Growth. New York: Pelican Book.

Barry, G. 1975. Economic Analiysis Before Adam Smith: Hesiod to Lessius. London: Macmillan.

Beckmann, M. J. 1975. The limits to growth in a neoclassical world. American Economic Review, 65(1975):695-99.

Budiman, A. 1994. Teori Pembangunan dan Dunia Ketiga. Jakarta: Gramedia Pustaka Utama.

Chapra, U. 2000. The Future of Economics: an Islamic Perspective. Leicester: The Islamic Foundation.

Damanhuri, D.S. 2010. Ekonomi Politik dan Pembangunan: Teori, Kritik, dan Solusi bagi Indonesia dan Negara Sedang Berkembang. Bogor: IPB Press.

Davies, R. \& G. Davies. 1996. The History of Money From Ancient Time to Present Day. London: University of Wales Press.

Domar, E. 1946. "Capital expansion, rate of growth and employment." Econometrica, 14(1946):137- 147.

Foster, J. B. \& F. Magdof. 2009. The Great Financial Crisis: Cause and Consequence. New York: Monthly Review Press.

Friedman, T.L. 2001. The Lexus and The Olive Tree: Understanding Globalization. New York: Achor Books.

2006. The World is Flat: The Globalized World in The Twenty - First Century. New York: Anchor Books.

Galbraith, J.K. 1992. The Culture of Contentment. Boston: Houghton Mifflin.

Giddens, A. 1999. Jalan Ketiga/The Third Way. Jakarta: Gramedia, 1999.

Greenfeld, L. 2001. The Spirit of Capitalism: Nasionalism and Economics Growth. Cambridge: Harvard University Press.

Harvey, D. 2005. A Brief History of Neoliberalismeism. New York: Oxford University Press.

Hasan, A.A. 1986. Sales and Contracts in Early Islamic Commercial Law. Edinburg: University of Edinburg. 
Hatta, M. 1967. Teori Ekonomi, Politik Ekonomi dan Orde Ekonomi. Jakarta: Tintamas.

--------. 1985. Membangun Ekonomi Indonesia. Jakarta: Inti Idayu Press. -. 2005. Indonesia Merdeka. Yogyakarta: Pustep-UGM.

Haq, M. 1971. Employment and Income Distribution in the 1970's. Islamabad: Hyderabad.

Hendra, E. 1995. "Regional Income Disparities". Bulletin of Indonesia Economic Studies. Vol.XI No. 1.

Huntington, S.P. 1999. The Clash of Civilization and The Remarking of world Order. New York: Oxford University Press.

Homer, S. \& R. Sylla. 1998. A History of Interest Rates. London: Rutgers University Press.

Kahf, M. 1978. The Islamic Economy: Analitical Study of the Foundationing of Islamic System. Indiana: MSA of USA and Canada.

Karim, A.A. 2007. Ekonomi Mikro Islami. Jakarta: PT Raja Grafindo Persada.

Krugman, P. 2003. The great Unraveling: Losing Our Way in The New Century. New York: W.W. Norton \& Company.

Kuncoro, M. 1997. Ekonomi Pembangunan. Yogyakarta: UPP AMP YKPN.

Madjid, A. \& S.E. Swasono (ed). 1981. Wawasan Ekonomi Pancasila. Jakarta: UI Press.

Mankiw, N.G. 2003. Macroeconomics. New York: Worth Publisher.

Mirakhor, A. 1993. "Equilibrium in a Non-Interest Open Economy." Journal of King Abdul Aziz University 5 (1993): 20.

Myrdal, G. 1957. Economics Theory and Under-Developed Regions. London: Gerald Duckworth.

Nasution, A. 1983. Financial Institution and Policies in Indonesia. Singapore: ISEAS.

Nasution, M.E, dkk. 2006. Pengenalan Eksklusif Ekonomi Islam. Jakarta: Kencana.

Perkins, J. 2004. Confession of an Economics Hit Man. San Fransisco: Barrett-Koehler Publisher.

Petras, J. \& H. Veltmeyer. 2001. Globalization Unmasked: Imperialism in the 21st Century. New York : Zed Books.

Polanyi, K. 2001. The Great Transformation: The Political and Economic Origins of Our Time. Boston: Beacon Press.

Rahardjo, M.D. 1999. Islam dan Tranformasi Sosial Ekonomi. Jakarta: Lembaga Studi Filsafat dan Agama.

Rahman, A. 1996. Economic Doctrines of Islam, Edisi Indonesia. Doktrin Ekonomi Islam. Yogyakarta: Dana Bhakti Wakaf. 
Ramli, R. dkk. 1997. Liberalisasi Ekonomi dan Politik di Indonesia. Yogyakarta: Tiara Wacana Yogya.

Rodrik, D. 2007. Trade Liberalization in Developing Countries: Do Imperfect Competition and Scale Economies Matter?. The American Economic Review vol 97, 2007: 283.

Robinson, J. 1962. Economics Philosophy. Harmondsworth: Penguin Book.

Salim, E. 1965. Sistem Ekonomi dan Ekonomi Indonesia. Jakarta: Lembaga Ekonomi dan Kemasyarakatan Nasional, MIPI.

Shidiqi, M. N. 1995. Philosophy of Islamic Economics. Jeddah: IRTI.

Schumpeter, J. 1972. History of economic Analysis. New York: Oxford University Press.

Smith, A. 1997. An Inquiry into Nature and Causes of the Wealth of Nation. With Introduction by Andrew S. Skinner. London: Penguin Books.

Stiglitz, J.E. 2002. Globalization and its Discontent. New York: W.W Norton \& Company.

Swasono, S.E. 2005. Ekspose Ekonomika: Mewaspadai Globalisasi dan Pasar Bebas. Yogyakarta: Pusat Studi Ekonomi Pancasila.

--_------. 2005. Kebersamaan dan Asas Kekeluargaan: Mutualism and Brotherhood. Jakarta: UNJ-Press.

2010. "Tingkatkan Pengawasan Perdagangan." Surat Kabar Harian Kompas, 28 Januari 2010.

- 2010. Indonesia dan Doktrin Kesejahteraan Sosial: dari Klasikal dan Neoklasikal Sampai ke The End of Laissez-Faire. Jakarta: Perkumpulan Prakarsa.

Jakarta: Yayasan Hatta.

Todaro, M.P. 1990. Ekonomi Pembangunan Di Dunia Ketiga. Jakarta : Erlangga. Wie, T.K. 1982. Perekonomian di Negara Berkembang. Jakarta: Pustaka Jaya. Thurow, L.C. 1994. Economics Explained. New York: Simon Schuster.

Vadillo, U. 1991. The End of Economics an Islamic Critique of Economics. Granada: Madinah Press.

------. 2002. The Architecture of the Gold Dinar Economy: An Academic Perspective. Proceedings of 2002 International Conference on Stable and Just Global Monetary System. 19-12 August 2002, Kuala Lumpur, Malaysia. --.--..- 2002. The Return of Islamic Gold Dinar. Cape Town: Madinah Press.

Vogel, F.E. \& S.L. Hayes. 1998. Islamic Law and Finance: Religion. Risk, and Return. London: Kluwer Law International 